\title{
Systematic Literature Review of Urban Poor Livelihoods in Malaysia
}

\author{
Nur Fatima Aisya Jamil, Nor Hafizah Mohamed Harith, Nur Zafifa Kamarunzaman \\ Fakulti Sains Pentadbiran dan Pengajian Polisi, \\ Universiti Teknologi MARA (UiTM), 40450 Shah Alam, Selangor, Malaysia. \\ nur.fatima.aisya@gmai.com, norha561@uitm.edu.my, nurzafifa@uitm.edu.my \\ Tel: 0127060433
}

\begin{abstract}
This paper aims to conduct a Systematic Literature Review (SLR) to examine the urban poor livelihood analysis through the lens of Sustainable Livelihood Approach (SLA) in Malaysia. SLA is a widely adopted framework for examining rural livelihoods globally and nationally, however there are limited studies that have adopted the SLA to examine urban poor household livelihoods. Hence, this paper aims to fill a gap of knowledge on analysing sustainability of urban poor livelihoods in Malaysia. Adopting Transparent Reporting of Systematic Reviews and Meta-Analyses method known as PRISMA, the results of SLR revealed significant urban livelihood themes are financial, human, social and physical capitals. These findings help policymakers and local support groups in improving the current policies and to enhance the quality of life of the urban poor.
\end{abstract}

Keywords: urban poor livelihoods, Malaysia, systematic literature review, Sustainable Livelihood Approach

eISSN: 2398-4287C 2020. The Authors. Published for AMER ABRA cE-Bs by e-International Publishing House, Ltd., UK. This is an open access article under the CC BYNC-ND license (http://creativecommons.org/licenses/by-nc-nd/4.0/). Peer-review under responsibility of AMER (Association of Malaysian Environment-Behaviour Researchers), ABRA (Association of Behavioural Researchers on Asians) and cE-Bs (Centre for Environment-Behaviour Studies), Faculty of Architecture, Planning \& Surveying, Universiti Teknologi MARA, Malaysia.

DOI: https://doi.org/10.21834/ebpj.v5i14.2273

\subsection{Introduction}

Malaysia's robust economy has led to rapid urbanisation since its independence in 1957. However, some scholars have indicated that the rapid urbanisation has divided the society into the division of income groups, namely the bottom 40 (B40), upper and middle class (M40), and high-income achiever (T20). Interestingly, the M40 and T20 are the main drivers for the expansion of the economic activities in the country. On the other hand, the B40 or the lower-income group in the country is struggling to make ends meet.

Although Malaysia has successfully eradicated poverty and uplifted the quality of life of the rural poor, due to the rapid urbanisation process in Malaysia, it is worth investigating the conditions of the livelihoods of the urban poor mainly among the B40 that reside in major cities in Malaysia. Meanwhile, there has been extensive literature on poverty research in Malaysia (Ibrahim, Hassan, Kamaruddin, \& Anuar, 2018; Neo, Mohamad, \& Satar, 2018). Nevertheless, there are limited studies that have adopted a sustainable livelihood approach to examine the conditions of the urban poor household livelihoods.

Hence, the main aim of the paper is to conduct a Systematic Literature Review (SLR) to examine the realities and lived experiences of urban poor individuals. The SLR has adopted Transparent Reporting of Systematic Reviews and Meta-Analyses method known as PRISMA. This method has mapped out the empirical studies on the poor urban livelihoods in the Malaysian context, delineated knowledge gaps as well as providing recommendations for future studies. The outcome of the SLR is significant not only in leading the direction of future research, but more importantly also, it taps new insights into the analysis of poor urban livelihoods in Malaysia. Consequently, it would be significant for the policymakers and local support groups to employ the outcomes as a guide to improve the current policies and tap on the quality of life of the urban poor.

\subsection{Purpose of The Study}

The purpose of this paper is to systemise the empirical knowledge of the livelihood of the urban poor in Malaysia. This builds up comprehensive literature of the realities of the urban poor through the Sustainable Livelihood Approach developed by the Department

eISSN: 2398-4287@ 2020. The Authors. Published for AMER ABRA cE-Bs by e-International Publishing House, Ltd., UK. This is an open access article under the CC BYNC-ND license (http://creativecommons.org/licenses/by-nc-nd/4.0/). Peer-review under responsibility of AMER (Association of Malaysian Environment-Behaviour Researchers), ABRA (Association of Behavioural Researchers on Asians) and cE-Bs (Centre for Environment-Behaviour Studies), Faculty of Architecture, Planning \& Surveying, Universiti Teknologi MARA, Malaysia.

DOI: https://doi.org/10.21834/ebpj.v5i14.2273 
for International Development (1999). It includes the vulnerabilities and livelihood strategies adopted by urban poor to cope with the risks and shocks.

\subsection{Research Question}

The main research question of this paper surrounds on "What is the livelihood context of the urban poor households in Malaysia?"

\subsection{Literature Review}

The Sustainable Development Goals is an international framework that Malaysia signed in commitment to reduce poverty and aspire for cities to be sustainable. Despite Malaysia experiencing an annual growth rate due to the expansion of economic activities and rapid urbanization, this does not trickle down to the whole citizens as pockets of urban poverty persist (Unit Penyelarasan Pelaksanaan, 2019). It is to be noted that urban poverty is distinct from its rural counterpart in an economic, environmental, social and political context which render their livelihood insecurity distinctive (Diehl, 2020). Among these differences, it includes that urban livelihoods are derived from non-agricultural markets and dependent on cash incomes as opposed to the rural livelihoods depending on natural capitals such as agriculture, livestock, forestry, and fishing (Rakodi \& Lloyd-Jones, 2002). Furthermore, in an urban setting, access to land and building materials are highly commercialised and challenging to obtain as compared to being in rural areas (Rakodi \& Lloyd-Jones, 2002). Despite infrastructures and services being limited in rural areas, it is still difficult for urban poor households to access them due to poor governance (Rakodi \& Lloyd-Jones, 2002).

The body of literature surrounding urban poverty is mostly on economics which lacks depth as it fails to capture the multidimensional nature of poverty (Siwar, Ahmed, Bashawir, \& Mia, 2016). Thus, a holistic approach is through livelihood analysis to build a picture on the livelihoods of the urban poor through their daily experiences (Diehl, 2020). Most studies adopting Sustainable Livelihoods Approach (SLA) focus on rural areas (Woyesa \& Kumar, 2020; Deng, Li, \& Zhang, 2020). In Malaysian context, most studies adopting SLA focus on rural and peri-urban areas (Ibrahim, Hassan, Kamaruddin, \& Anuar, 2018; Neo, Mohamad, \& Satar, 2018) but minimal SLA studies in urban areas. This paper adopts the sustainable livelihood approach, which is a tool to enhance the comprehension of livelihoods of the urban poor in which are reflected upon to improve poverty reduction strategies in Malaysia. The components of the Sustainable Livelihood Approach include (1) vulnerability context, (2) livelihood assets, (3) policies, institutions and processes, (4) livelihood strategies and (5) livelihood outcomes as portrayed in Figure 1.

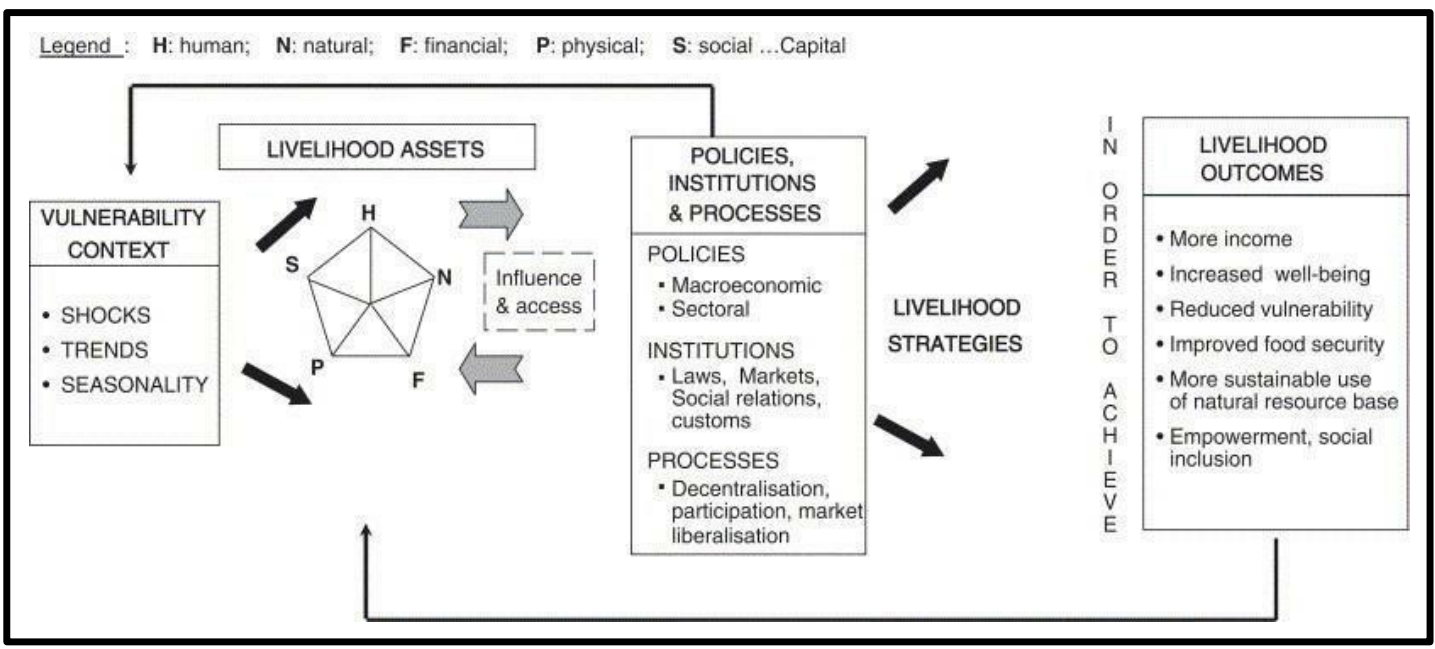

Fig. 1: Sustainable Livelihood Approach

(Source: Department for International Development, 1999)

The vulnerability context refers to the condition of the external environment exposed by the urban poor which affects their ability and livelihood assets in coping with trends, shocks and seasonality (Diehl, 2020). The management and access of these livelihood assets formed livelihood strategies in determining the living of the urban poor household (Diehl, 2020). The definition of assets is portrayed in Table 1.

Table 1. Definition of Assets

\begin{tabular}{|l|l|}
\hline Assets & Definition \\
\hline Natural Capital & $\begin{array}{l}\text { The practice of urban agriculture and utilisation of natural resources such as rivers } \\
\text { for livelihoods such as washing, drinking, poultry and fishing. }\end{array}$ \\
\hline Human Capital & The capacity to work as labourer, having sets of skills, knowledge and good health. \\
\hline Financial Capital & $\begin{array}{l}\text { The components of capital base, such as cash, credit/debt, savings, and other } \\
\text { economic assets. }\end{array}$ \\
\hline Social Capital & $\begin{array}{l}\text { The social resources (networks, social claims, social relations, affiliations, } \\
\text { associations) for reciprocity, trust and source of information. }\end{array}$ \\
\hline
\end{tabular}




\begin{tabular}{|l|l|}
\hline Physical Capital & $\begin{array}{l}\text { The economic and social infrastructure (buildings, roads, public amenities, public } \\
\text { transportation), production equipment and technologies, livestock and housing. }\end{array}$ \\
(Source: Ahmed, Siwar, \& Idris, 2011)
\end{tabular}

These assets are influenced by the policies, institutions and processes which create, determine access or influence asset accumulation (Department for International Development, 1999). Households make decisions based on their asset portfolio for devising livelihood strategies against the stress through stinting, hoarding, protecting, depleting, diversifying, claiming and moving assets to generate positive livelihood outcomes (Chambers \& Conway, 1992).

Therefore, the purpose of this research is to review empirical studies and to synthesise the knowledge based on urban poor livelihoods by mapping out the current empirical research in Malaysia to include the conceptualisation of urban poverty and identify study objectives and key findings. Thus, knowledge gaps are determined to provide recommendations for future research.

\subsection{Methodology}

\subsection{PRISMA}

The systematic literature review adopts a Transparent Reporting of Systematic Reviews and Meta-Analyses known as Preferred Reporting Items for Systematic Reviews and Meta-Analyses (PRISMA) to guide the search, filtering, selection, and analysis of the research questions of this article (PRISMA, 2015). The steps provided in the PRISMA guidelines are identification, screening, eligibility, and inclusion (PRISMA, 2015). The resources used are Scopus and Web of Science databases. Scopus indexed over 14,000 journals and 2850 social science titles from 4000 publishers, while Web of Science records 33,000 journals with 5,200 social science publications (Burnham, 2006; Clarivate Analytics, 2020). Both of these databases are the best coverage for social science research.

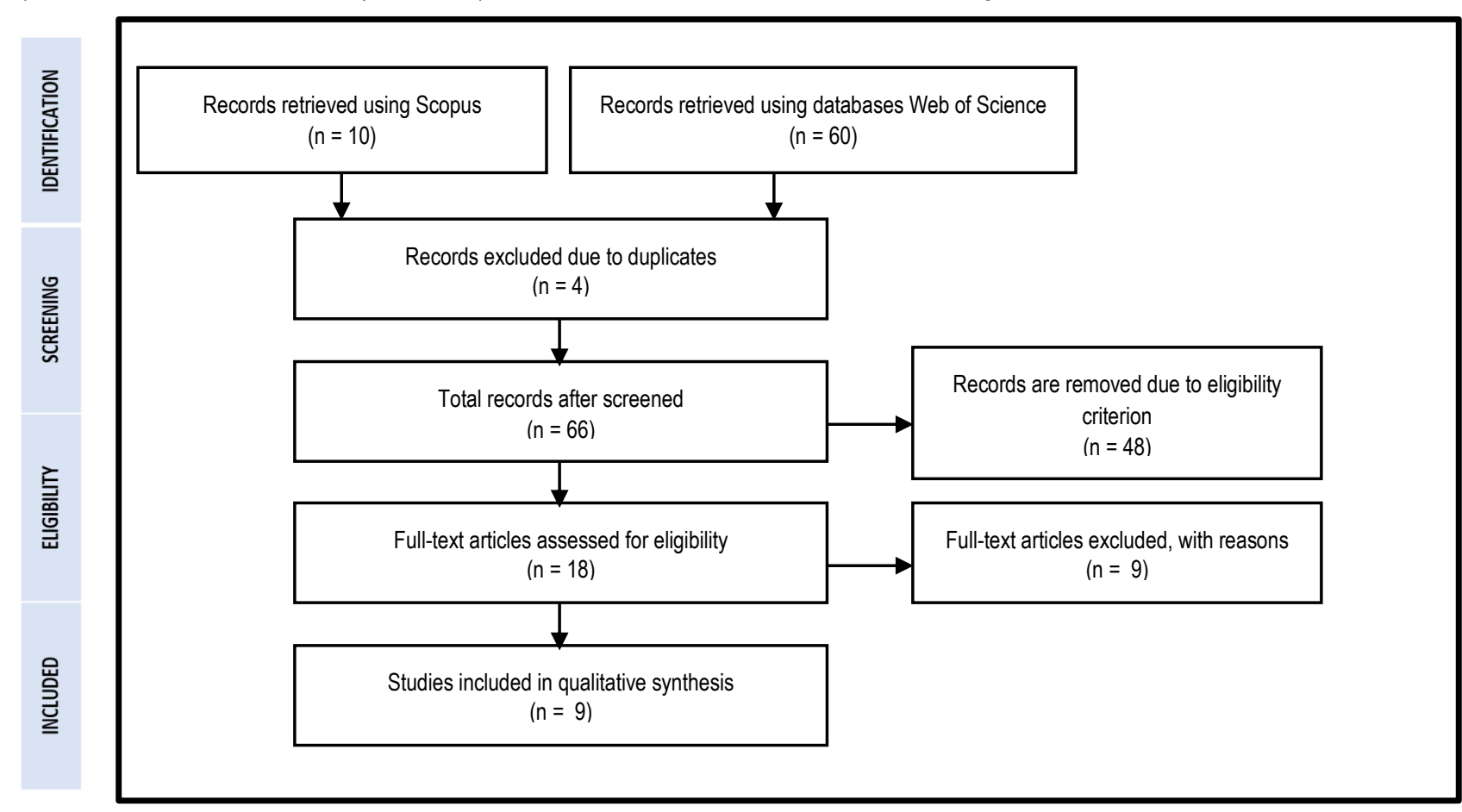

Fig. 2: Selection of Articles Flow Diagram

(Source: Moher D, Liberati A, Tetzlaff J, Altman DG, The PRISMA Group, 2009)

The first phase of the SLR is to identify the keywords to use as search strings for the database search. Through careful deliberation, the search terms are determined as portrayed in Table 2. During the search, ten records were retrieved through Scopus, and 60 from the Web of Science database. In the second step, screening, the investigation found four records had a duplicate entry, and these entries were removed; thus, 66 articles remained.

Table 2. Search terms

\begin{tabular}{|l|l|}
\hline Terms & Search Strings \\
\hline Poverty & $\begin{array}{l}\text { Poverty OR poor OR vulnerability OR "socioeconomic level" OR "socioeconomic } \\
\text { status" OR low income OR inequality OR inequity }\end{array}$ \\
\hline Urban areas & $\begin{array}{l}\text { Urban area city OR urban* OR semiurban* OR periurban* OR "inner city" OR } \\
\text { metropolis OR metropolitan }\end{array}$ \\
\hline Livelihoods & $\begin{array}{l}\text { vulnerab* OR "household strateg" OR "survival strateg*" OR "coping } \\
\text { strateg*" OR livelihood* }\end{array}$ \\
\hline Malaysia & Malaysia \\
\hline
\end{tabular}


Next, for the eligibility criterion, the inclusive criteria are portrayed in Table 3 , and the selection of articles are depicted in Figure 2. After reading abstracts of these 66 articles, 48 articles were removed as it is not based in Malaysia and were not urban poverty-focused. Thus, 18 articles remained, and when these articles were read, nine articles were excluded due to its irrelevance as they did not focus on urban poverty and were not empirical research; instead they were concept papers and literature reviews. There are nine articles included for qualitative synthesis, which three of these articles used qualitative methods while the remaining six employed quantitative methods.

Table 3. Eligibility criterion

\begin{tabular}{|l|l|}
\hline Criterion & Eligibility \\
\hline Country & Malaysia \\
\hline Language & English and Malay \\
\hline Timeline & Between 2020 and 2000 \\
\hline
\end{tabular}

\subsection{Thematic Analysis}

This paper synthesises nine empirical research through thematic analysis. Thematic analysis is a method in identifying, analysing, organising, describing and reporting themes arising from qualitative data to produce trustworthy and insightful findings (Nowell, Norris, White, \& Moules, 2017). Thus, this paper adopts a qualitative method using thematic analysis in summarising key features of these nine articles to shape the main themes of the livelihoods of the urban poor in Malaysia.

\subsection{Findings}

Based on the thematic analysis, the main themes of the livelihoods of the urban poor in Malaysia are financial capital, human capital, physical capital and social capital as portrayed in Table 4. The next subsection will elaborate on each of the themes that emerged.

Table 4. The main themes of livelihoods of the urban poor in Malaysia

\begin{tabular}{|l|l|l|c|c|c|c|}
\hline No. & Author & Method & Financial Capital & Human Capital & Physical Capital & Social Capital \\
\hline 1 & Yusmah et al. (2020) & Qualitative & & & $\checkmark$ & $\checkmark$ \\
\hline 2 & Azhar and Mohd (2019) & Quantitative & $\checkmark$ & $\checkmark$ & & \\
\hline 3 & Al-Shami et al. (2015) & Quantitative & $\checkmark$ & & & \\
\hline 4 & Sathasivam (2015) & Quantitative & & $\checkmark$ & & \\
\hline 5 & Zahari and Ariffin (2013) & Qualitative & & & $\checkmark$ & $\checkmark$ \\
\hline 6 & Siwar et al. (2013) & Quantitative & & $\checkmark$ & & \\
\hline 7 & Sulaiman and Masud (2012) & Quantitative & $\checkmark$ & & & \\
\hline 8 & Sulaiman et al. (2011) & Quantitative & & $\checkmark$ & & \\
\hline 9 & Ghazali (2003) & Qualitative & $\checkmark$ & & & $\checkmark$ \\
\hline & Total & & 4 & 4 & 2 & 3 \\
\hline
\end{tabular}

\subsection{Financial Capital}

Firstly, financial capital has been identified through the livelihoods of urban poor in participating in microfinance, saving schemes and vulnerabilities of overbearing household expenditure. The urban poor, especially women, have access to microfinance via Amanah Ikhtiar Malaysia (AIM) which becomes a credit source for income and investment by building their capacities in becoming selfsufficient (Al-Shami et al., 2015). The urban poor is involved in savings to use during emergencies if their income is suddenly cut-off, an unexpected financial expense and financial shocks (Azhar \& Mohd, 2019; Yusof, Jusoh \& Rokis, 2013; Ghazali, 2003). However, the ageing urban poor are unprepared to finance their retirement years as they have low savings and investments, which is exacerbated by the cost of living and cost of healthcare (Sulaiman \& Masud, 2012).

Another issue faced by most urban poor is the higher number of children attending school, which reflects on the higher expenditures in clothing, books and pocket money. In order to balance their spending, they might reduce food expenditure, leading to food insecurity (Sulaiman et al., 2011). In this sense, the head of the family usually cut down high-quality or expensive items such as animal-source foods, fruits, vegetables and dairy products (Sulaiman et al., 2011). Thus, the action would risk poor dietary quality and quantity due to lacking intake of energy and nutrients (Sulaiman et al., 2011). On the other hand, the urban poor also trim their daily expenditure, borrowed from friends and family, pawned their assets, borrowed from loan sharks and partake in more than one job (Yusof, Jusoh \& Rokis, 2013; Ghazali, 2003).

\subsection{Human Capital}

The human capital refers to the household members contributing to sustaining livelihoods, education and health. Human capital is perceived as a valuable asset for urban poor households, especially in financial contribution. Usually, the households have a dualincome family, where both husband and wife are working. Although in most urban households who particularly hold patriarchal principle believes the husband is primarily the breadwinner, however in this poverty situation, the wife is welcomed to help to ease the burden. Interestingly, wives who did not have extensive education turn their domestic skills into income generation activities. For example, business from home involves cooking, sewing, and creative arts; or opening small food stalls (Azhar \& Mohd, 2019). However, the women expressed insecurity in exposing themselves in a rough environment, which may invite harm to them. Apart from the head of 
the household, other household members generate income as well and pool their income together because households would consume less without pooling resources (Azhar \& Mohd, 2019; Ghazal, 2003).

Education plays an essential role in reducing poverty as those with low education levels are vulnerable to poverty (Azhar \& Moh, 2019; Siwar et al., 2013). However, the urban poor face a burden in sending their children to school as it is far from home (Azhar \& Mohd, 2019). The fact that having more children in the family means more contribution financially in future; however, not all parents from urban poor share the same idea on the importance of their children's education. While some parents believe that education is the ticket to graduate from the cleavage of poverty, the majority of the parents from this vulnerable group are giving reasons for not sending their children to school (Azhar \& Mohd, 2019; Siwar et al., 2013). Therefore, the effort of breeding the country's human capital may be distorted in the B40 income group as the mindset is not consistent with the government efforts to end the poverty issues.

Moreover, an essential component of human capital is health. The ageing urban poor are also vulnerable because they are frail, causing their inability to age independently and deteriorating health status (Sathasivam, 2015). Poor health and help-seeking behaviour have been reported in numerous social, medical research (Sathasivam, 2015). Most of the urban poor are associated with suffering from non-communicable diseases such as diabetes, cardiovascular disease, and even cancer (Sathasivam, 2015). In a similar vein, effective healthcare in Malaysia has caused a rapid growth of grey society or an ageing population. However, according to Sathasivam (2015), the type of ageing society in Malaysia is those that are socially and financially dependent as well as experiencing deteriorating in their health status. Often, they are more dependent on the government hospital than getting personal insurance, which they cannot afford even when they are young. Hence, it gives a burden to the country in terms of healthcare, housing, nursing care, and monetary.

\subsection{Physical Capital}

Physical capital refers to the infrastructures that help the urban poor sustain their livelihoods which are often impeded by flooding and climate change. Although flood is anticipated as a yearly event, the urban poor are still vulnerable due to the demography and location of their houses (Yusmah et al., 2020; Zahari \& Ariffin, 2013). Moving to another area would cost much to the family who has limited resources; hence the only option is to continuously stay in the hazardous area (Zahari \& Ariffin, 2013). At the systemic level, an improper flood control infrastructure from the government and related agencies are identified to worsen the urban poor livelihoods (Yusmah et al., 2020).

The government plays a crucial role in resilience against climate change as Malaysia faces the challenge of flooding. The urban poor is vulnerable to inaccurate information, improper evacuation plan, mismanagement of transit centres and lack of preparation causing victims to have insufficient time to prepare for emergencies (Yusmah et al., 2020). This creates a slow recovery process (Yusmah et al., 2020). On the other side of the coin, the government has taken proactive action in mitigating the impact of such natural disasters, especially for poor households. The urban poor communities are given an avenue to share their knowledge and experience while facing disasters, and the data are used to help the government in formulating an effective emergency kit and guideline during emergencies. The effort also promotes the sustainability of the communities by adapting affordable structural modifications (Zahari \& Ariffin, 2013).

\subsection{Social Capital}

Furthermore, the urban poor develops social capital by forming a network through cooperation in the community. An example of this is that despite the absence of flood warning systems, the urban poor develop their own community-based risk communication (Zahari \& Ariffin, 2013). These communities personally monitor for signs of flooding and make public announcements at the prayer hall (surau) to alert others about any risks of flooding as well as instruction for evacuation and safety measures (Zahari \& Ariffin, 2013). The urban poor women also mobilise their social networks and organise informal credit schemes among neighbours and working peers (Ghazali, 2003). This enables them to pool money and provide financial services to those who need it; thus, empowers women as well as contribute to family welfare and household economy (Ghazali, 2003).

\subsection{Discussions}

The findings revealed significant themes that include financial capital, human capital, social capital and physical capital. Hence, based on the SLR, it revealed that the urban poor households are managing these capitals to face susceptibility to risks, vulnerabilities and shocks in the cities. Furthermore, different contexts of the social, economic and political environment of the urban setting do affect their livelihood adversely (Rakodi \& Lloyd-Jones, 2002). Indeed, previous scholars have discussed the concepts of vulnerability, sustainable livelihoods, assets management and coping mechanisms among the urban poor (Chambers \& Conway, 1992; Diehl, 2020; Rakodi \& Lloyd-Jones, 2002). Globally, research on sustainable livelihood was highly focused on studies on the Sustainable Livelihood among the rural community have shown the importance of livelihood assets to the poor community to achieve sustainable livelihoods (Rakodi \& Lloyd-Jones, 2002). The SLR reviews have shown the empirical research done on rural community in Malaysia were centered on most of the five capitals (Al-Shami et al., 2015; Mohamad Azhar \& Mohd, 2020; Safiah Yusmah et al., 2020; Sathasivam, Kamaruzzaman, Hairi, Ng, \& Chinna, 2015; Siwar, Ahmed, \& Idris, 2013; Sulaiman \& Masud, 2012; Sulaiman et al., 2011; Zahari \& Ariffin, 2013). As derived from the aforementioned studies, the urban poor are the vulnerable groups, including those with low income, elderly, women, ranges from ethnicity and mostly, disaster preparedness (Yusmah et al., 2020; Azhar and Mohd, 2019; Al-Shami et al., 2015; Sathasivam, 2015; Zahari and Ariffin, 2013; Siwar et al., 2013; Sulaiman and Masud, 2012; Sulaiman et al., 2011; Ghazali, 2003). Thus, this SLR leads to fill a research gap into an in-depth analysis of the urban poor household livelihoods through the lens of SLA. 


\subsection{Conclusion}

There is a limited number of literature on the livelihoods of the urban poor and the dynamics surrounding these studies are on ethnicity, gender, ageing and disaster preparedness. Urban issues exemplified by the persistence of urban poverty proves that there is a need to have a comprehensive understanding of the livelihoods of the urban poor. This is because Malaysia aspires for sustainable cities by promoting inclusivity for all. The findings conclude that the urban poor have strengths deriving from their livelihood assets mainly the financial capital, human capital, physical capital and social capital. However, from these aspects, the urban poor are facing vulnerabilities that impede their livelihoods. It is noted that the majority of the urban poor population are vulnerable to financial shocks and they are not resilient to stresses, shocks and seasonal trends living in the metropolitan cities. This also shows that the urban poor livelihoods are determined by their abilities to manage their livelihood assets that would result in achieving a sustainable livelihood outcome. Finally, a future study is recommended to address the gap of knowledge on urban poor household livelihoods through the lens of Sustainable Livelihoods Approach in Malaysia. This could assist Malaysian government to continuously empower the urban poor households' capabilities and capacities to battle against poverty.

\section{Acknowledgements}

The authors would like to thank the Ministry of Higher Education for financially supporting this research grant (Fundamental Research Grant Scheme) and the Faculty of Administrative Science and Policy Studies, Universiti Teknologi MARA.

\section{References}

Ahmed, F., Siwar, C., \& Idris, N. A. H. (2011). The sustainable livelihood approach: Reduce poverty and vulnerability. Journal of Applied Sciences Research, 7(6), 810813.

Al-Shami, S. S., Majid, I., Rizal, S., Muhamad, M. R., \& Rashid, N. (2015). The impact of Malaysian microfinance on women livelihood. Advanced Science Letters, 21(6), 2046-2049.

Azhar, N. A. Z. M., \& Mohd, S. (2020). Using asset index to reassess poverty in the Northern States of Malaysia: do the poor stay poor?. International Journal of Social Economics, 47(7), 483-502

Burnham, J. F (2006) Scopus Database: A Review. Biomedical Digital Libraries, 3(1).

Chambers, R., \& Conway, G. R. (1992). Sustainable Rural Livelihoods: Practical Concepts for the 21st Century. IDS Discussion Paper 296. Institute of Clarivate Analytics. (2019) 2019 Journal Citation Reports.

Clarivate Analytics. 2020. Web of Science: Confident Research Begins Here. Retrieved from https://clarivate.com/webofsciencegroup/solutions/web-of-science/

Deng, Q., Li, E., \& Zhang, P. (2020). Livelihood sustainability and dynamic mechanisms of rural households out of poverty: An empirical analysis of Hua County, Henan Province, China. Habitat International, 99, 102160.

Department for International Development. (1999). Sustainable Livelihoods Guidance Sheets. Development Studies, University of Sussex, Brighton, UK.

Diehl, J. A. (2020). Growing for Sydney: Exploring the Urban Food System through Farmers ' Social Networks. Sustainability, 12(8), 3346.

Ghazali, S. (2003). Kut (informal rotating credit) in The Livelihood Strategies of Urban Households in Penang, Malaysia. Area, 35(2), 183-194.

Ibrahim, A. Z., Hassan, K. H., Kamaruddin, R., \& Anuar, A. R. (2018a). The Level of Livelihood Assets Ownership Among Vulnerability Group in East Coast of Malaysia. European. Journal of Sustainable Development, 7(3), 157-161.

Liberati, A., Altman, D. G., Tetzlaff, J., Mulrow, C., Gøtzsche, P. C., loannidis, J. P., ... \& Moher, D. (2009). The PRISMA statement for reporting systematic reviews and meta-analyses of studies that evaluate health care interventions: explanation and elaboration. Journal of clinical epidemiology, 62(10), e1-e34.

Neo, S. H. S., Mohamad, J., \& Satar, N. binti M. (2018). The Use Of Sustainable Livelihoods Framework In Evaluating Fishery Policies In Pangkor Island. JATI-Journal of Southeast Asian Studies, 23(2), 1-21

Nowell, L. S., Norris, J. M., White, D. E., \& Moules, N. J. (2017). Thematic Analysis: Striving to Meet the Trustworthiness Criteria. International Journal of Qualitative Methods, 16(1), 1-13.

PRISMA (2015) Prisma: Transparent Reporting of Systematic Reviews and Meta-Analyses. Retrieved from http://www.prismastatementorg/PRISMAStatementFlowDiagram

Rakodi, C., \& Lloyd-Jones, T. (2002). Urban Livelihoods: A People-Centred Approach to Reducing Poverty. Routledge.

Sathasivam, J., Kamaruzzaman, S. B., Hairi, F., Ng, C. W., \& Chinna, K. (2015). Frail Elders in An Urban District Setting in Malaysia: Multidimensional Frailty and Its Correlates. Asia Pacific Journal of Public Health, 27, 52s-61s.

Scoones, I. (1998). Sustainable Rural Livelihoods: A Framework For Analysis. Working Paper 72, Institute for Development Studies, Brighton, UK.

Siwar, C., Ahmed, F., \& Idris, N. D. M. (2013, December). Relationship between Poverty and Socio-demographic Characteristics of Poor Households: A Case Study in Kelantan, Malaysia, 2013 International Conference on Advances in Social Science, Humanities, and Management (ASSHM-13). Atlantis Press. 
Siwar, C., Ahmed, F., Bashawir, A., \& Mia, M. S. (2016). Urbanization and Urban Poverty in Malaysia: Consequences and Vulnerability. Journal of Applied Sciences 16(4), 154-160.

South East Asia Community Observatory. (2016). A Study of Local Livelihoods: Using the Sustainable Livelihoods Approach.

Sulaiman, H., \& Masud, J. (2012). Determinants of Income Security of Older Persons in Peninsular Malaysia. Pertanika Journal of Social Science \& Humanities, 20(1) $239-250$

Sulaiman, N., Shariff, Z. M., Jalil, R. A., Taib, M. N. M., Kandiah, M., \& Samah, A. A. (2011). Validation of the Malaysian Coping Strategy Instrument to Measure Household Food Insecurity in Kelantan, Malaysia. Food and Nutrition Bulletin, 32(4), 354-364.

Unit Penyelarasan Pelaksanaan. (2019). Maklumat Tertumpu Golongan Miskin dan Miskin Tegar Mengikut Parlimen di Kuala Lumpur.

Woyesa, T., \& Kumar, S. (2020). Potential of coffee tourism for rural development in Ethiopia: a sustainable livelihood approach. Environment, Development and Sustainability, 1-18.

Yusmah, M. S., Bracken, L. J., Sahdan, Z., Norhaslina, H., Melasutra, M. D., Ghaffarianhoseini, A., ... \& Farisha, A. S. (2020). Understanding Urban Flood Vulnerability and Resilience: A Case Study of Kuantan, Pahang, Malaysia. Natural Hazards, 1-21.

Yusof, S. A. (2013). Risk Exposure, Risk-Bearing Capacity, And Risk-Coping Strategies of Urban Households, 10th EBES Conference Proceedings. Taksim Nippon Hotel Istanbul, Turkey.

Zahari, R. K., \& Ariffin, R. N. R. (2013). Community-based disaster management in Kuala Lumpur. Procedia-Social and Behavioral Sciences, 85, $493-501$. 